\title{
IAMJ
}

INTERNATIONAL

AYURVEDIC

MEDICAL JOURNAL

Review Article

ISSN: 2320-5091

Impact Factor: 6.719

\section{MANAGEMENT OF ANTIBIOTIC RESISTANCE BY AYURVEDA - A LITERARY REVIEW}

\author{
$\underline{\text { Mahendra Bande }}^{1}, \underline{\text { Smriti S Mishra }}^{2}, \underline{\text { Rajesh Kolarkar }}^{3}$
}

${ }^{1}$ Professor, Ayurveda Samhita and Siddhanta Dept, Dr. V.J.D. Gramin Ayurved Mahavidyalaya Patur, Maharashtra, India

${ }^{2}$ MD Ayurveda, Samhita and Siddhanta, Thane, Maharashtra, India

${ }^{3}$ H.O.D, Ayurveda Samhita and Siddhanta Dept, Y.M.T. Ayurvedic Medical College, Kharghar, Maharashtra, India

Corresponding Author: mishrasmriti333@gmail.com

\section{https://doi.org/10.46607/iamj2309082021}

(Published Online: August 2021)

Open Access

(C) International Ayurvedic Medical Journal, India 2021

Article Received: 06/07//2021 - Peer Reviewed: 14/07/2021 - Accepted for Publication: 15/07/2021

Check for updates

\section{ABSTRACT}

Background - Antibiotic resistance is rising to dangerously high levels worldwide. WHO's new Global Antimicrobial Surveillance System (GLASS) reveals widespread occurrence of Antibiotic resistance among 500000 people with suspected bacterial infections across 22 countries. India is no different from it, facing the problem of rising cases of multidrug-resistant TB which adds to the burden of infectious disease in India. Aim - In this literary review problem, current scenario, causes and solution on Antibiotic Resistance from an Ayurvedic perspective will be assessed. Methodology - Articles on Antibiotic Resistance from research papers, journals, and various sites and basic principles from Samhitas and various Ayurvedic Journals, Articles and Research papers on this perspective will be reviewed. Conclusion - Conclusion will be drawn after a thorough literature review on the above subject.

Keywords- Antibiotic Resistance, Panchkarma, Rasayana

\section{INTRODUCTION}

Antibiotics are medicines used to prevent and treat bacterial infections in clinical practice. Antibiotic resistance occurs when bacteria change in response to the use of these medicines. From all studies in India with 30 isolates or more, resistance rates of E Coli to third generation cephalosporins (new powerful drugs) 
were 82 per cent and fluoroquinolones were 86.4 per cent $^{1}$. In other words, the next time we need an antibiotic for a urinary tract infection, the antibiotics we take are not going to work most of the time. Antibiotic resistance is accelerated by the misuse and overuse of antibiotics, as well as poor infection prevention and control. A growing number of infections such as pneumonia, tuberculosis, gonorrhoea, and salmonellosis are becoming harder to treat as the antibiotics used to treat them become less effective. It leads to a large hospital stay, higher medical costs and increases mortality $^{2}$. This shows that the Antibiotic pipeline is running dry making infectious diseases a major threat to public health. Three promising advances move beyond direct killing to reduce disease severity, they are

1. The targeting of the effectors of pathogenicity rather than the pathogen itself.

2. Improving tissue damage control, thereby improving the host's capacity to tolerate pathogens.

3. Targeting the microbiome to build a natural line of defence against pathogens.

Every organism present in this world has praneshna i.e desire to live ${ }^{3}$. This is applied to pathogens like bacteria, viruses etc. Antibiotics try to kill the existence of pathogens, in response pathogens mutate to disallow antibiotics to kill them, and thus Antibiotic resistance develops. Ayurveda principles emphasize establishing a symbiotic relationship with nature without disturbing the existence of any organism in this world ${ }^{4}$. According to Ayurveda, immunity depends upon the maintenance of the equilibrium of Doshas and the healthiness of tissues and channels ${ }^{5}$. Similarly, the strength of the body is related to immunity, and it also depends upon the healthiness of tissue. Acharya Charak has emphasized that Bala i.e strength of the body can only control the imbalance of $\operatorname{doshas}^{6}$. Thus, indicating the significance of the concept of Bala for our immunity. So now our goal should be towards increasing the bala of our body. Bala can be increased in two ways according to the nature of doshas. In case of increased doshas, Samshodhana Chikitsa of Ayurveda, which includes panchakarma treatment, intends to eliminate the toxic elements from the body and thereby enhances the immunity of the body. The toxic products of body metabolism can be broadly divided into water-soluble, fat-soluble, and volatile substances. Volatile substances like carbon dioxide can be easily removed from the body through the lungs. While there are several mechanisms to get rid of water-soluble toxic materials through kidney, sweat and other body secretions. Removal of fat-soluble toxic materials is very difficult and only the liver can play a small role. Hence it is likely that there would be an accumulation of fat-soluble toxic products in the body. Liberal use of oil and ghee in various panchakarma procedures makes it possible to eliminate these fat-soluble toxic products. Thus, through these bio-cleansing processes balance of normal doshas can be established. The concept of "Ama" is also equally important in keeping check of increased vitiated doshas in our body. Ama is immunologically active but nutritionally insignificant, complexes generated in the intestine due to improper digestion of food. Ama has been implicated by the Ayurveda to be the part of the pathogenesis of several diseases like RA, Ulcerative Colitis etc. all of which we know have an immunological background. Deepak and Pachak medicine help to digest this Ama acting as immunoreactive agents since they modify immune-related disease ${ }^{7}$. Apart from these, a healthy microbiome can be kept through panchakarma and deepan pachan chikitsa as these treatments work on the GI tract. Basti treatment has a major role in improving the microbiome as its work best at pakwashaya (large intestine) which is the abode of gut flora ${ }^{8}$. Modern scientific medicine is gradually realizing that the mere presence of a causative agent in the environment or its entry into the body does not always result in the disease. The most important concerning health, the disease is the immunity of the body. Immunomodulation i.e modulation of the immune response through the selective use of immunomodulators is currently being considered the most potent method in the management of health and disease by modern medicine. Recent advances in understanding the neuroendocrine immune axis and the influence of nutrition, exercise, and circadian rhythms on it, are bringing modern medicine nearer to Ayurveda. The concepts of immunity and immunomodulation appear 
to have been extensively explored and used in Ayurveda particularly in Rasayana Tantra. It is a specialized treatment influencing the fundamental aspects of the organs i.e. Dhatus, Agni, and Strotamsi, leading to an overall improvement in the organism, which affords prevention of ageing, resistance against disease, bodily strength, and improvement in mental faculties. Acharya Charaka describes Rasayana as one which obtains longevity, regains youth, gets a sharp memory and intellect and freedom from disease gets a lustrous complexion and good strength. Acharya Sushruta is more specific in describing Rasayana as an anti-ageing one, increases the life span, promotes intelligence and memory and increases resistance to the disease presumably infections and therefore, indicating potential immunostimulant effects. The mode of action of Rasayana Dravyas can be considered through the following 3 ways

1. By improving the nutritional values of rasa dhatu in turn by improving the dhatu poshana e.g dugdha, ghrita, shatavari etc.

2. By improving the Agni Vyapara thereby responsible for proper Dhatunirmana in the body like Chitraka, Bhalltaka etc.

3. By Strotoshodhana in the body, this improves Dhatuposhana kriya like guggul $l^{9}$

\section{DISCUSSION}

After understanding the concepts of Ayurveda, in building immunity so that body can fight against any drug resistance pathogens, drugs and formulations which can do this task should be studied. The antioxidant potential of Bramha Rasayana ${ }^{10}$ and Amalaki Rasayana $^{11}$ are well known.

Apart from these formulations, several medicinal plants exhibit not only immunomodulatory activity but also a wide range of antioxidant, antihistaminic, antiinflammatory, hepatoprotective and other medicinal activities. Ocimum Sanctum, Centellia asiatica, Withania Somnifera, Acacia cathechu, Picrorrhiza scrophulariiflora, Plantago asiata, Panax ginseng, Allium sativum, Cynodon dactylon, Terminalia arjuna, Boerhhavia diffusa, Andrographis paniculate, Curcuma longa, Tinospora cordfolia, etc. are plants showing good immunomodulatory and antioxidant activity $^{12,13}$. Apart from these, there is a new concept "adaptogen" is emerging which supports immunogenic evidence. Adaptogens are defined as herbal preparations that increase attention and endurance in fatigue and reduce stress-induced impairments and disorders related to the neuroendocrine and immune systems. Asparagus racemosus, Convolvulus pluricaulis, Emblica Officinalis, Piper longum, Glycyrrhiza glabra etc are plants mentioned in literature as adaptogen ${ }^{14}$.

\section{CONCLUSION}

Management of Antibiotic resistance can be done in the following ways. Firstly, in case of increased doshas state panchakarma treatment, and deepan and pachan should be done which will help in building healthy microbiome flora resulting in boosting immunity. In case of decreased and vitiated doshas state adequate use of Rasayana treatment and use of proper immunomodulator and antioxidant herbal drug according to disease should be done to boost immunity thus combating Antibiotic resistance problem. Thus, targeting the effectors of pathogenicity and improving tissue control can be well achieved by Rasayana treatment and for the development of a healthy microbiome, panchakarma treatment will be ideal.

\section{REFERENCES}

1. R Laxminarayan, why antibiotic resistance is getting worse in India, down to earth,7 June 2015.

2. https://www.who.int 5 Feb 2018.

3. Pedro F. Vale et all, beyond killing can we find new ways to manage infection, Evolution Medicine and Public health, Issue 1, January 2016, page 148-157.

4. Tripathi RD, Shukla AV, Caraka Samhita, Chaukhambha Sanskrit Pratistan, Delhi, 2011, page 162.

5. Shastri KA, Susruta Samhita, Chaukhambha Sanskrit Sansthan, Varanasi,2013, vol 1, page 84.

6. Tripathi B, Caraka Samhita, Chaukhambha Surbharati Prakashan, Varanasi, 2014, vol 1, page 176.

7. Gupta B et al, Observations on Vamana procedure in healthy volunteers, Ayu 2011, Jan-Mar, 32(1), 40-45.

8. Tripathi B, Caraka Samhita, Chaukhambha Surbharati Prakashan, Varanasi, 2014, vol 1, page 292. 
9. Sharma Brahmadutt et al, A review article regarding enhancing immunity through Ayurveda, UJAHM 2016, 04(03), page 8-11.

10. Rekha PS, et al, Antioxidant Activity of Brahma Rasayana, Indian J Exp Biol, 2001 May, 39(5), 447-52.

11. SMS Samarakoon, HM Chandola, VJ Shukla, Evaluation of Antioxidant potential of Amalakayas RasayanaA Polyherbal Ayurvedic formulation, International Journal of Ayurveda Rasayana,2011 Jan-Mar 2(1), 2328.

12. Singh N, Tailang M, Mehta SC, A review of herbal plants as immunomodulators, IJPSR, 2016, 7(9), 360210.

13. Kumar D, Arya V, Kaur R et al, A review of immunomodulators in the Indian traditional health care system, Journal of microbiology, immunology, and infection, vol 45, issue 3, June 2012, page 165-184.

14. Panossian A, Wagner H, Adaptogens. A review of their history, biological activity and clinical benefits. Herbal Gram. 90.01/05/2011.

\section{Source of Support: Nil \\ Conflict of Interest: None Declared}

How to cite this URL: Smriti S Mishra et al: Management of Antibiotic Resistance By Ayurveda - A Literary Review. International Ayurvedic Medical Journal \{online\} 2021 \{cited August 2021\} Available from: http://www.iamj.in/posts/images/upload/1744_1747.pdf 